\title{
Volcanic related methylmercury poisoning as the possible driver of the end-Devonian Mass Extinction
}

\author{
Michą RAKOCIŃSKI ${ }^{1 *}$, LESZEK MARYNOWSKI ${ }^{1}$, \\ AGNIESZKA PISARZOWSKA ${ }^{1}$, JACEK BEŁDOWSKI ${ }^{2}$, \\ GRZEGORZ SIEDLEWICZ ${ }^{2}$, Michą ZATON' ${ }^{1}$, MARIA \\ Cristina Perri ${ }^{3}$, Claudia Spalletta ${ }^{3}$, AND Hans \\ PETER SCHÖNLAUB ${ }^{4}$
}

${ }^{1}$ University of Silesia in Katowice, Institute of Earth Science, Będzinska str. 60, 410200 Sosnowiec, Poland; michal.rakocinski@us.edu.pl, leszek.marynowski@us.edu.pl, agnieszka.pisarzowska@us.edu.pl, mzaton@wnoz.us.edu.pl

${ }^{2}$ Institute of Oceanology, Polish Academy of Sciences, Powstańców Warszawy 55, 81-712 Sopot, Poland, hyron@iopan.gda.pl, gsiedlewicz@iopan.gda.pl

${ }^{3}$ Department of Biological, Geological and Environmental Sciences, University of Bologna, via Zamboni 67, 40126 Bologna, Italy; mariacristina.perri@unibo.it, claudia.spalletta@unibo.it

${ }^{4}$ Austrian Academy of Sciences, Commission for Geosciences, 2, Dr. Ignaz Seipel-Platz, Vienna, 1010, Austria; hp.schoenlaub@aon.at

The end-Devonian global Hangenberg event (359 Ma) is among the most devastating mass extinction events in Earth's history, albeit not one of the "Big Five". This extinction is linked to worldwide anoxia caused by global climatic changes. These changes could have been driven by astronomical forcing and volcanic cataclysm, but ultimate causes of the extinction still remain unclear. Here we report anomalously high mercury $(\mathrm{Hg})$ concentration in marine deposits encompassing the Hangenberg event from Italy and Austria (Carnic Alps). The Hangenberg event recorded in the sections investigated can be here interpreted as caused by extensive volcanic activity of large igneous provinces (LIPs), arc volcanism and/or hydrothermal activity. Our results imply volcanism as a most possible cause of the Hangenberg event, similar to other first order mass extinctions during the Phanerozoic. For the first time we show that apart from anoxia, proximate kill mechanism of aquatic life during the event could have been methylmercury formed by biomethylation of a volcanically derived, huge concentration of inorganic $\mathrm{Hg}$ supplied to the ocean. Methylmercury as a much more toxic $\mathrm{Hg}$ form, potentially could have had a devastating impact on end-Devonian biodiversity, causing the extinction of many pelagic species. 